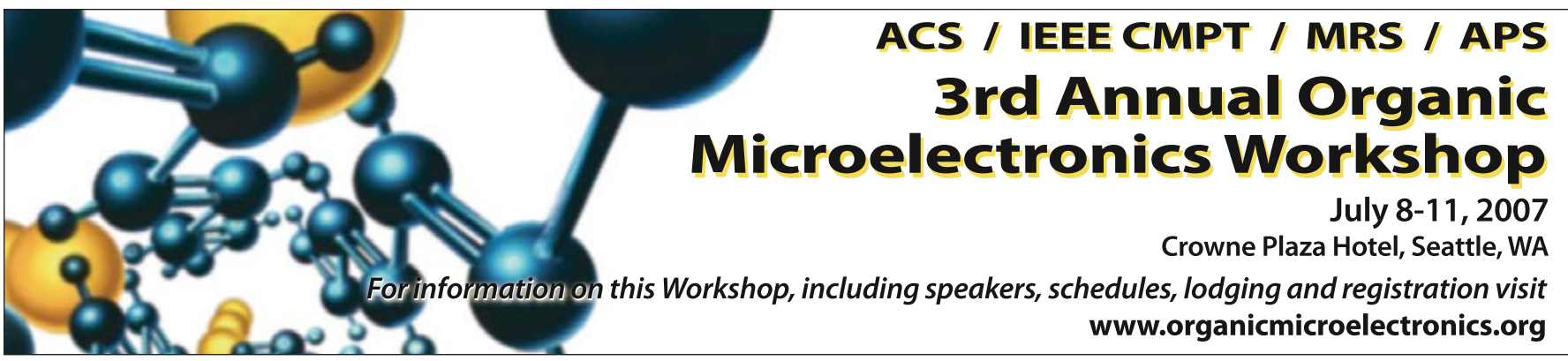

POSTERMINARIES

\title{
Books Do Furnish a Room
}

I recently moved my office for the third time in two years. Our Department of Engineering is being re-structured and re-furbished. Many of you would call it re-modeling and I wish it was literally only modeling, which might involve planning and programming but no demolition crew, carpenters, or painters! However, four moves it must be (one more to get to my final destination) so I have taken each move as an opportunity to review my professional possessions. The first decisions were easy and I reduced my need for filing cabinets by about $40 \%$ at each move-at the expense of back strain shifting the re-cycling bags full of paper. Then I looked at my book shelves. I have had a life-long love-love relationship with books and had accumulated more than 1000 books, theses, and journal volumes. In the age of the web, how many of these could I now justify, and what should I do with the rest?

Again, the first decision was easy-offer the journals to the library, and trash the ones they did not want. Done. The second stage was to set up a "yard sale" (or rather a "yard giveaway") on a table outside my office door and e-mail my colleagues and all our students, asking them to help themselves. This re-housed a hundred or so volumes, but another hundred or so had to be trashed. Then I was down to the hard core. What had to remain?

With one move to go (and then retirement is not far off, so my wife's views will also need to come into play), this is where I am:

Books with my name on the spine- - preserved out of pure vanity, despite their low intrinsic value, particularly the older ones.

My students' theses-reprieved for the moment for reasons of nostalgia. But can they survive the next cull, when the fact that they are big and heavy and the library holds each master copy will be a telling argument?

Books written to support the teaching and learning of various aspects of mate-

"I have had a life-long love-love
relationship with books and had
accumulated more than 1000
books, theses, and journal volumes.
In the age of the web, how many
of these could I now justify, and
what should I do with the rest?"

rials science (such as thermodynamics, dislocation theory, alloy theory, and semiconductor physics). All have gone, in a victory of realism over nostalgia in recognition that not only do I not teach these topics now, but in some cases I never have taught them! Many of these texts were collected in a spirit of optimistic pseudo-professionalism, on the premise that I should be equipped to teach any core topic if necessary. All the volumes are under-used, and some of them remain unopened since they arrived. What a weight off my shoulders and shelves. Just once, recently, I thought I might regret this draconian action. I was explaining critical nucleus size to a student, and glibly started to say, "You can read it up in..."-but the book was gone. However, two clicks in a web search located excellent lecture notes (someone else's of course) and the problem was solved.

The most dog-eared book on my shelves, I now realize, is the 1962 Dover edition of Carmichael and Smith's Mathematical Tables and Formulas. I have not used the tables since about 1970, but the list of formulas has been consulted with great regularity. This is probably the only book on my shelves to have been opened every year since I graduatedapart from my English dictionary, which has had to be replaced twice in that time. So I am going to keep Carmichael \& Smith for a while yet.

It seems still to be true that the world expects an academic to have shelves of books, so what do mine now look like? I have managed to reduce the total from 1000 to 150 volumes, of which about 30 are theses and 20 or so relate to the topics I currently teach (mainly project management, not metallurgy). Most of these will go in the next cull, so what types of book will make it through to the final?

I will keep books that offer opinions, not facts, or insights, not knowledge and I am lucky enough to know many of their authors, who have enriched my life in person as well as through their writing. These are likely to include Rod Cotterill's Cambridge Guide to the Material World (much more than a coffee-table book, with a second edition due soon); Robert Cahn's thoughtful essays and his contribution to the debate about the origins and nature of our discipline, The Coming of Materials Science; Steve Sass's Substance of Civilization; Phil Ball's Made to Measure (albeit a little too chemical for my taste); Ivan Amato's Stuff (the best choice of title, by far, and the best introduction to the range and excitement of our discipline for a non-scientist); and Ken Easterling's Tomorrow's Materials (for a reminder of what the future looked like 20 years ago).

Finally, if I had to select just one book, which happens also to be the smallest and lightest and out of print, it would be What's the Use of Lectures? by Donald Bligh, published by Penguin in 1971 and bought by me in 1972. Bligh's main conclusion is "not much" and this is the book that changed my life from materials researcher to educator. The complete transition took a long time but it really has been worth it and I will keep that particular $150 \mathrm{~g}$ of well-researched common sense in my office, however often they move me.

PS: Books Do Furnish a Room is a novel by Anthony Powell, the 10th in the sequence of 12 comprising his masterpiece, A Dance to the Music of Time.

PETER GOODHEW 